\title{
PEMBELAJARAN BAHASA ARAB DARING BERBASIS STRATEGI KARRONA DI MASA PANDEMI COVID-19
}

\author{
Maria Ulfah Syarif \\ email: ulvamaria11@gmail.com \\ Institut Agama Islam Negeri (IAIN) Bone, Indonesia
}

\begin{abstract}
One of the obstacles in the implementation of online learning during Covid-19 pandemic is the lack of lecturers and students's readiness in mastering $e$ learning support applications. In addition, the large amount of assignments precisely can trigger students' psychosocial stresses that may diminsih the online learning effectiveness. The lecturers, therefore, are required to be more creative to make an interesting learning, including in Arabic learning. Karrona, an innovative learning strategy, is a song media-based method focusing on strengthening the understanding of qawaid substance that is applied to overcome the ineffectiveness of online learning Arabic. This study then aims to investigate how the effectiveness of Karrona strategy to increase qawaid understanding and to improve vocabulary mastery in online Arabic learning during pandemic covid-19. This research employed a mixed method design, involving the mixing of both quantitative and qualitative approach. This study involved 176 students of IAIN Bone as well as used observation and questionnaires techniques to collect the data. The major findings of this study show that the Karrona strategy is briefly effective in increasing student interest and motivation to learn Arabic. Moreever, this strategy can improve students' qawāid understanding and mufradāt mastery.
\end{abstract}

Keywords: Online learning, Arabic language, Karrona strategy

\section{PENDAHULUAN}

Fenomena beralihnya sistem pembelajaran konvensional menjadi virtual di tengah upaya pemerintah memutus mata rantai penyebaran virus Covid-19 menuai banyak kritikan dan keluhan. Kritikan dan keluhan tersebut menjadi bahan penelitian di kalangan akademisi dan melahirkan opini di kalangan masyarakat luas. Pemberlakuan pembelajaran daring mengingatkan prediksi Thomas L. Friedman bahwa kedepan perkuliahan mahasiswa akan 
menjadi lebih fleksibel. Cukup duduk depan komputer yang tersambung dengan jaringan internet, mahasiswa sudah dapat melakukan proses perkuliahan (Watnaya et al., 2020).

Di sisi lain, fakta di lapangan menunjukkan bahwa pembelajaran daring justru menuai banyak keluhan, baik oleh mahasiswa sendiri maupun oleh orang tua mahasiswa. Beban tugas yang terlalu banyak di hampir seluruh mata kuliah menyebabkan tekanan dan kejenuhan pada mahasiswa. Hal ini melahirkan kecemasan yangdapat berujung menjadi stressor psikosial bagi mahasiswa. Hal ini sejalan dengan hasil studi Watnaya et al (2020) yang menunjukkan adanya potensi peningkatan tekanan mental mahasiswa selama pembelajaran online. Selain itu, keluhan terkait pembelajaran online dilayangkan oleh orang tua mahasiswa atas pembengkakan biaya dalam pemenuhan kuota data selama proses pembelajaran daring di masa pandemi covid-19.

Beberapa penelitian terkait pembelajaran online selama masa pandemi covid-19 yang ada pada saat ini setidaknya dibagi menjadi tiga kategori. Pertama, studi yang meneliti tentang gambaran pelaksanaan serta hambatan dan kendala pembelajaran daring (Anugrahana, 2020; Hutauruk \& Sidabutar, 2020; Rigianti, 2020; Sadikin \& Hamidah, 2020). Kedua, penelitian mengenai variasi model dan platform yang digunakan dalam pembelajaran daring selama masa pandemi (Gunawan et al., 2020; Kusuma \& Hamidah, 2020; Suhendro, 2020). Ketiga, studi tentang pengaruh dan dampak pembelajaran online pada masa pandemi covid-19 (Rahmasari et al., 2020; Argaheni, 2020).

Secara khusus, penelitian yang mengkaji tentang pembelajaran Bahasa Arab di masa pandemi covid-19 diantaranya studi terkait kajian media yang digunakan pada pembelajaran online (Wargadinata et al., 2020) serta gambaran pembelajaran bahasa Arab di SD (Zullaini et al., 2020). Penelitian-penelitian tersebut hanya sebatas mengkaji gambaran pelaksanaan, tantangan, serta penggunaan media dan platform dalam pembelajaran Arab secara online. Temuan studi terdahulu tersebut juga terkait seputar kendala yang dialami siswa dalam pembelajaran Arab secara online. Penelitian terdahulu telah mengkaji ketidakefektifan pembelajaran Arab secara online namun minus solusi konkretnya. Olehnya itu, penelitian ini berupaya mengisi celah tersebut dengan menggambarkan bagaiman upaya membuat pembelajaran bahasa Arab daring menjadi lebih efektif melalui sebuah strategi pembelajaran inovatif yakni strategi Karrona.

Strategi Karrona merupakan strategi pembelajaran berbasis media lagu/nyanyian sebagai solusi pemecahan dari akumulasi problematika pembelajaran bahasa Arab daring dan ketidak efektifannya. Dengan berbekal pengetahuan kaidah bahasa Arab dasar yang 
telah diperoleh pada semester sebelumnya, mahasiswa ditugaskan untuk menghafalkan sebuah lagu/nyanyian yang mana sebelumnya lirik dari lagu/nyanyian tersebut terlebih dahulu harus mereka telaah berdasarkan pengetahuan kaidah bahasa Arab yang mereka ketahui. Setelah ditelaah barulah kemudian lagu/nyanyian tersebut mereka hafalkan. Kelebihan dari strategi ini adalah lagu/nyanyian yang mereka hafalkan dapat berdampak pada penguatan pemahaman qawāid yang telah mereka pelajari disamping bertambahnya mufrādat (kosa kata) sekaligus sebagai hiburan di tengah-tengah suasana pembelajaran daring yang dilematis.

Studi ini berangkat dari tiga argumen. Pertama mahasiswa dengan kemampuan dasar yang berbeda-beda serta penguasaan aplikasi belajar daring yang minim, belum siap menjalani proses pembelajaran bahasa Arab via secara online. Kedua, mahasiwa membutuhkan suasana belajar dengan kondisi fisik dan psikis yang rileks dalam menjalani pembelajaran daring yang sarat beban pemenuhan tugas. Ketiga, strategi Karrona berbasis media lagu ditawarkan untuk memanfaatkan kekuatan musik dan lirik lagu dalam mengatasi kejenuhan mahasiswa dalam belajar daring. Belum ada penelitian terdahulu yang mengkaji tentang penggunaan strategi Karrona, khususnya dalam pembelajaran online di masa pandemi covid-19. Hal demikian menjadi aspek kebaruan penelitian ini sehingga layak untuk dikaji secara lebih mendalam.

\section{METODE}

Penelitian ini bertujuan untuk menganalisis bagaimana efektifitas penerapan strategi Karrona dalam meningkatkan pemahaman qawāid dan penguasaan kosakata mahasiswa dalam pembelajaran bahasa Arab daring di masa pandemi covid-19. Melalui penelitian ini, respon mahasiswa dalam menjalani proses pembelajaran bahasa Arab daring dengan menerapkan strategi karrona selama masa pandemi covid-19 akan dianalisis.

Penelitian ini menggunakan mixed method design, kombinasi dari pendekatan kualitatif dan kuantitatif (C. Creswell, 2009). Berdasarkan tipologi riset, penelitian ini diklasifikasikan sebagai concurrent design tipe triangulasi. Dalam tipologi ini, data kualitatif dan kuantitatif dikumpulkan dan dianalisis pada waktu yang bersamaan. Namun, proses analisis kedua data dilakukan secara terpisah dan proses integrasi keduanya dilaksanakan pada tahap interpretasi (J. W. Creswell, 2012; Hanson et al., 2005). Pada penelitian ini, data kualitatif dan kuantitatif memiliki prioritas yang sama, dikumpulkan secara independen dan terpisah namun dalam periode waktu yang relatif sama. 
Penelitian dimulai sejak bulan April sampai Mei 2020 dengan jumlah responden sebanyak 176 orang mahasiswa semester dua tahun ajaran 2019-2020 dari program studi Hukum Tata Negara (HTN) Fakultas Syariah dan Hukum Islam IAIN Bone. Mahasiswa yang menjadi subjek penelitian memiliki kemampuan kognitif yang heterogen.

Teknik pengumpulan data yang digunakan adalah observasi dan kuesioner daring menggunakan google form. Melalui observasi dan kuisioner tersebut dapat dilihat bagaimana respon mahasiswa terhadap strategi Karrona yang ditawarkan dosen pengampu dalam mengatasi kejenuhan mahasiswa menjalani proses pembelajaran Bahasa Arab daring. Hal sekaligus menjadi tolok ukur sejauhmana efektifitas penerapan strategi Karrona dalam pembelajaran daring yang sarat dengan dampak psikologi dan ekonomi.

\section{HASIL DAN PEMBAHASAN}

Pengetahuan dan penguasaan materi bahasa Arab yang dimiliki oleh mahasiswa tingkat awal dipengaruhi oleh beberapa faktor. Salah satunya adalah faktor latar belakang pendidikan. Perbedaan latar belakang pendidikan sangat berpengaruh terhadap pengetahuan dan penguasaan materi bahasa Arab yang dimiliki oleh mahasiswa. Mahasiswa dengan latar belakang pendidikan berbasis umum (SMU dan SMK) rata-rata memiliki pengetahuan dan pemahaman yang minimin seputar materi bahasa Arab karena selama menjalani pendidikan mereka tidak pernah menerima materi bahasa Arab sama sekali. Bahkan ada sebahagian di antara mereka yang masih kesulitan dalam membaca dan menulis bahasa Arab dengan baik. Berbeda dengan mahasiswa yang berbasis agama (alumni MA dan Pondok Pesantren) yang tentu saja memiliki bekal pengetahuan bahasa Arab minimal pernah belajar materi bahasa Arab sebelum menjalani perkuliahan di perguruan tinggi (IAIN Bone).

\section{Latar belakang pendidikan sebelum PT 176 tanggapan}

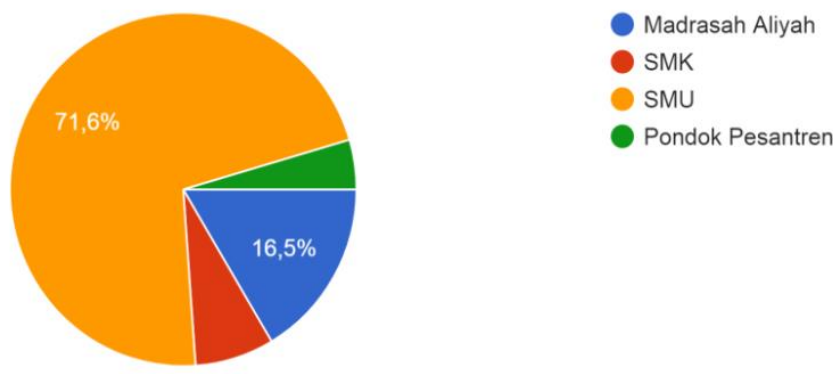

Gambar 1. Latar Belakang Pendidikan Responden 
Gambar 1 menyajikan karakteristik latar belakang mahasiswa prodi HTN semester II yang menjadi subjek penelitian ini sebelum menjalani pendidikan di perguruan tinggi (IAIN Bone). Berdasarkan gambar 1, terlihat bahwa dari 176 orang respoden, sebanyak 71,6\% dari mahasiswa dengan latar belakang pendidikan dari Sekolah Menengah Umum (SMU), dan hanya sekitar 16,5 \% yang yang berlatar belakang pendidikan Madrasah Aliyah. Selebihnya 11,9\% adalah mahasiswa dari Sekolah Menengah Kejuruan (SMK) dan Pondok Pesantren. Dengan demikian, hanya sebagian kecil mahasiswa responden yang memiliki dasar pengetahuan Bahasa Arab dari jenjang pendidikan sebelumnya. Tingkat kemampuan penguasaan Bahasa Arab seluruh responden juga sangatlah heterogen.

Berangkat dari fakta bahwa setiap mahasiswa memiliki karakteristik yang beragam, maka secara otomatis diperlukan pendekatan pembelajaran yang berbeda-beda pula sesuai dengan keragaman karakteristik tersebut. Dalam menentukan kegiatan belajar mengajar yang sesuai, pada dasarnya dapat dirancang melalui pendekatan kelompok atau pendekatan individual, tergantung pada tujuan khusus yang ingin dicapai (Sanjaya, 2006; Turdjai, 2016). Tentu saja pendekatan pembelajaran yang dilakukan akan memiliki konsekuensi terhadap tugas-tugas belajar yang harus dilakukan peserta didik. Pendekatan kelompok merupakan pembelajaran di mana peserta didik belajar secara kelompok, baik dalam kelompok besar ataupun kecil. Sedangkan pendekatan individual adalah pembelajaran dimana peserta didik belajar secara mandiri melalui bahan belajar yang dirancang sedemikian rupa, sehingga peserta didik dapat belajar menurut kecepatan dan kemampuan masing-masing. Pada proses pembelajaran daring selama masa pandemi, pembelajaran mata kuliah bahasa Arab diterapkan pendekatan individual yaitu setiap mahasiswa belajar mandiri di rumah masingmasing dengan bahan ajar/materi bahasa Arab dasar yang dibagikan melalui platform Whats App yang disertai penjelasan singkat dosen pengampu melalui aplikasi zoom.

Meskipun proses pembelajaran daring adalah hal yang baru, namun antusiasme mahasiswa dan dosen pengampu cukup baik. Hal tersebut dapat dilihat dari hasil angket yang ditunjukkan pada gambar 2 yakni sebanyak $96 \%$ responden mengaku rutin dalam mengikuti proses perkuliahan daring selama masa pandemi Covid-19. Demikian halnya dengan antusiasme dosen pengampu yang telah membersamai mahasiswa menjalani social distancing namun tetap melaksanakan kewajiban berdasarkan tupoksi sebagai dosen dengan tetap melakukan proses perkuliahan bahasa Arab Dasar 2 secara daring dengan baik dan sesuai jadwal. 


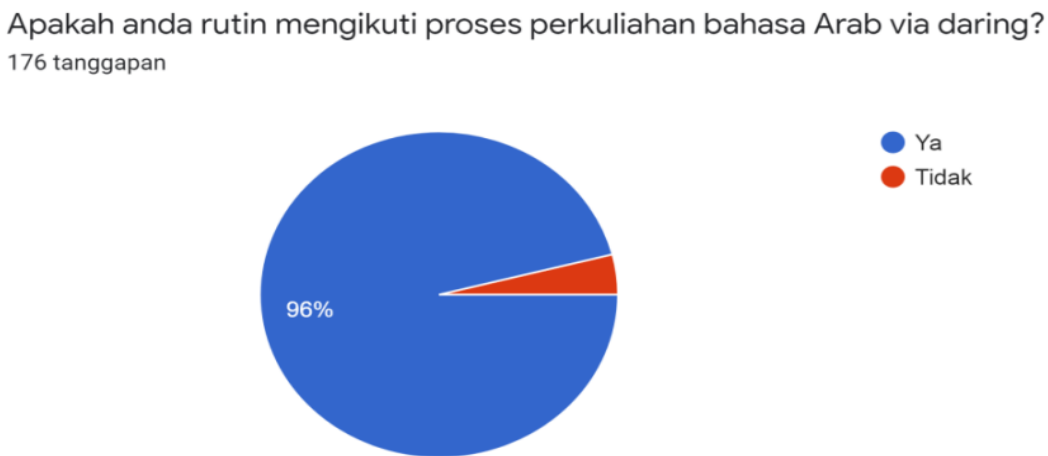

Gambar 2. Keaktifan Responden Mengkuti Pembelajaran Daring

Secara umum, persepsi mahasiswa terhadap proses pembelajaran daring terbilang baik. Sebanyak 47,7\% mahasiwa memberi respon bahwa perkuliahan berjalan dengan baik dan 46,6 \% memberi penilaian cukup. Artinya hanya 5,7\% menilai proses pembelajaran kurang menarik. Namun, tidak dapat dipungkiri jikalau pemberlakuan sistem perkuliahan daring yang secara tiba-tiba awalnya adalah sebuah keterpaksaan baik bagi dosen pengampu maupun bagi mahasiswa. Hal itu tentu saja menjadi sebuah tantangan baru terlebih bagi dosen. Dosen pengampu dituntut untuk dapat meramu ulang kembali materi pembelajarannya menyesuaikan dengan media yang akan digunakan. Termasuk metode pembelajaran yang juga harus disesuaikan. Secara konkret, tidak semua dosen siap menjalankan pembelajaran online karena tidak semuanya memiliki kemampuan dalam menguasai IT termasuk ketidakmampuan mengoperasikan platform dan aplikasi daring pendukung proses pembelajaran daring. Sehingga tidaklah berlebihan manakala kemudian di tengah hiruk pikuknya pembelajaran daring muncul asumsi bahwa pembelajaran daring selama masa pandemi jauh dari kata efektif karena ketidaksiapan pendidik dan peserta didik.

Permasalah lain yang muncul dalam pembelajaran daring adalah mahasiswa justru disibukkan dengan aktivitas pemenuhan tugasdari dosen, hampir di semua mata kuliah. Situasi ini tak pelak semakin menambah ketidakefektifan pembelajaran. Tuntutan pemenuhan tugas di tengah-tengah keterbatasan pada masa pandemi melahirkan kecemasan yang berujung keletihan dan kejenuhan pada diri mahasiswa. Kondisi serupa turut dirasakan oleh mahasiswa responden, sebagaimana tergambar pada gambar 3. 


\section{Apakah Anda pernah merasa jenuh dengan sistem perkuliahan bahasa Arab via daring? 176 tanggapan}
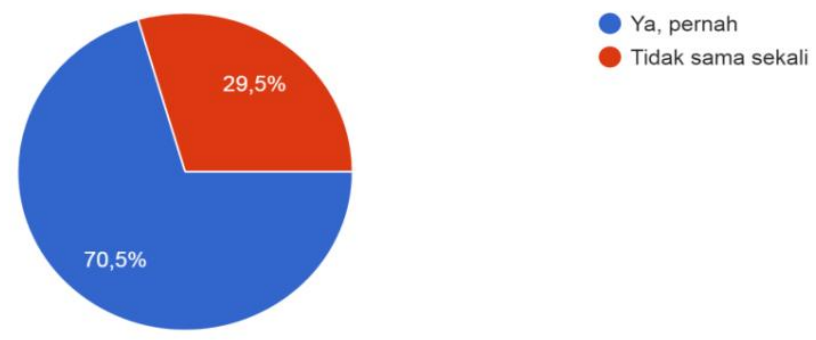

Gambar 3. Kejenuhan Responden Menjalani Pembelajaran Daring

Data pada gambar 3 menunjukkan bahwa hanya sebesar 29,5\% mahasiswa yang merasa tidak pernah jenuh sama sekali dalam menjalani proses pembelajaran bahasa Arab via daring. Selebihnya sebanyak $70,5 \%$ mahasiswa merespon betapa mereka pernah dihinggapi rasa jenuh dengan sistem perkuliahan bahasa Arab via daring. Adalah hal yang wajar, mengingat materi bahasa Arab Dasar 2 adalah kelanjutan dari materi bahasa Arab Dasar 1 yang setingkat lebih rumit dari materi sebelumnya. Sementara keterbatasan dosen dalam menjelaskan materi lanjutan karena terhambat oleh beberapa faktor yang bersifat problematik dalam memandu proses perkuliahan daring.

Berdasarkan hasil observasi dan data kuesioner, secara umum problematika yang dihadapi oleh mahasiswa dalam pembelajaran bahasa Arab daring meliputi beberapa faktor. Keterbatasan jaringan dan paket kuota internet menjadi kendala utama yang dirasakan responden dalam menjalani proses pembelajaran daring selama masa pandemi. Alasan utama mahasiswa tidak mengikuti pembelajaran daring pada waktu yang telah dijadwalkan adalah karena sulitnya mengakses jaringan internet (bagi mereka yang bermukim di daerah yang jauh dari kota), bahkan tidak jarang mereka yang sedang mengikuti proses pembelajaran daring tiba-tiba terhenti karena kehabisan paket data internet saat tengah mengikuti pembelajaran dengan video conference. Sebanyak 127 orang mahasiswa atau $72,2 \%$ responden mengakui bahwa kendala yang dirasakan sangat berpengaruh pada pembelajaran online adalah keterbatasan jaringan/keterbatasan mengakses materi melalui aplikasi pembelajaran daring. Selanjutnya, 92 orang responden (52,3\%) merasakan ketidakseimbangan antara tingginya biaya pembelajaran daring dan taraf ekonomi keluarganya sehingga mereka merasa terkendala dalam pemenuhan kuota data.

Tidak dapat dipungkiri, keterbatasan kemampuan memaparkan materi bagi dosen pengampu-karena hanya paham pada penggunaan platform Whats App yang dipadu dengan 
aplikasi zoom ditambah lagi dengan durasi waktu penggunaan dari platform/aplikasi yang digunakan-sangat mempengaruhi cara dosen memaparkan dan menjelaskan materi bahasa Arab dari slide PPT yang disajikan. Secara luring kebiasaan mahasiswa menyimak pemaparan materi dosen melalui slide PPT yang disertai dengan penjelasan materi secara detil dengan metode ceramah ditunjang media whiteboard untuk pemaparan contoh-contoh kalimat dari materi kaidah yang dibahas. Namun secara daring dosen pengampu hanya mampu membagikan materi via slide PPT dengan metode ceramah via zoom dan diskusi via WA grup. Perubahan sistem tersebut tentu sajaberpengaruh pada tingkat kemampuan mahasiswa dalam menangkap informasi seputar materi. Kendala media pembelajaran semacam ini diungkapkan oleh sebanyak 57 orang $(32,4 \%)$ responden sebagai salah satu faktor problematik dalam pembelajaran daring.

Faktor media pembelajaran tersebut harus mendapat perhatian, sebab media sangat berpengaruh pada cara dosen memaparkan materi khususnya dalam memberi contoh pelafalan kata dan kalimat. Sebanyak 53 orang (30,1\% responden) yang merasa terkendala pada pelafalan kata dan kalimat dan 25 orang (14,2\% responden) yang merasa terkendala dalam hal materi.

\section{Penerapan Strategi Karrona}

Tujuan pembelajaran bahasa Arab jika dilihat pada sisi pendidik adalah agar dapat menjadikan bahasa Arab mudah dikuasai oleh para pelajar, sementara bagi pelajar tujuannya adalah agar dapat menguasai bahasa Arab (Mustofa \& Hamid, 2016). Untuk mencapai tujuan tersebut, harus melalui proses yang tidak terlepas dari tahap-tahap pemerolehan bahasa itu sendiri. Yang diperoleh setelah terjadinya interaksi antara dosen dan mahasiswa dalam sebuah proses pembelajaran yang efektif dan efisien tentunya.

Perlu memperhatikan beberapa faktor yang turut berpengaruh pada efektifitas pembelajaran selain interaksi antara dosen dan mahasiswa. Faktor yang dimaksud adalah faktor media dan instrumen pembelajaran, fasilitas belajar, sistem pembelajaran dan evaluasi, kurikulum, metode, dan strategi (Hidayat, 2012; Yulita, 2014). Lebih terperinci lagi, Sumardi (1996) mengungkapkan bahwa fenomena pembelajaran bahasa Arab yang kurang berhasil dipengaruhi oleh beberapa faktor yang dipandang signifikan, di antaranya: (1) Guru hanya banyak menekankan teori dan pengetahuan bahasa dibanding keterampilan berbahasa. (2) Bahan pelajaran tidak relevan dengan kebutuhan siswa baik secara lisan ataupun tulisan tetapi banyak berkisar pada pembahasan tentang unsur-unsur bahasa seperti: 
fonologi, orfologi, dan sintaksis, serta kurang aplikatif dalam menggunakan unsur-unsur bahasa tersebut. (3) Proses pembelajaran lebih banyak didominasi oleh guru, kurang memberikan kesempatan kepada peserta didik untuk berperan aktif. (4) Struktur bahasa dibahas secara terpisah, kurang integratif dan kurang menekankan kebermaknaan, struktur bahasa yang diajarkan lepas dari konteks sosial budayanya. (5) Sistem penilaian lebih banyak menekankan asfek kognitif, dan tidak menuntut keterampilan bahasa secara integratif.

Berangkat dari teori tersebut maka dari itu menyikapi fenomena pembelajaran bahasa Arab daring yang terkesan tidak efektif akibat terkontaminasi oleh ragam problematika pembelajaran daring dan stressor psikosial maka lahirlah ide untuk melanjutkan proses perkuliahan bahasa Arab via daring dengan tidak lagi menambah materi qawā'id bahasa Arab. Tanpa maksud mengurangi esensi dari pembelajaran materi bahasa arab dasar sebagaimana mestinya. Pembelajaran kemudian dilanjutkan dengan memberikan penguatan atas pemahaman dan penguasaan mahasiswa dari materi-materi qawā'id yang telah diperoleh sebelumnya (selama semester satu dan materi awal pertemuan di semester dua) dengan menerapkan strategi Karrona kepada mahasiwa dalam pembelajaran bahasa arab daring.

Strategi Karrona merupakan sebuah strategi yang diterapkan guna untuk menarik minat dan menumbuhkan motivasi mahasiswa dalam mempelajari bahasa arab dalam hal ini untuk menambah perbendaharaan kosa kata/ mufradat. Strategi ini diterapkan sejak minggu ke 9 pembelajaran daring setelah mahasiswa mendapatkan beberapa materi kaidah dasar bahasa Arab pada semester satu (16 kali pertemuan) dan 6 kali pertemuan di awal semester dua.

Kata Karrona pada strategi ini adalah istilah yang diambil dari singkatan Karrora alGināayang artinya mengulang-ulangi lagu, yaitu gabungan dari kata Karroro dan alGinā $u$. Karroro dalam bahasa arab adalah fi'il mādhi atau kata kerja dari akar kata Karroro - Yukarriru - Takrīra yang artinya mengulang sesuatu, berbuat berulang-ulang. Sedangkan kata al-Ginā' adalah isim dengan akar kata Ginā un-Agniyyatun jamaknya Agānnìyang berarti lagu atau nyanyian.

Strategi ini dinamakan sebagai Karrona (Karrora al-Ginā’a) dengan dasar bahwa selama penerapan proses pembelajaran berlangsung, strategi ini menjadikan sebuah lagu/nyanyian sebagai materi utama dalam pembelajaran selama 2-3 pekan dengan tahapan sebagai berikut: 
1. Pekan pertama materi berupa lagu/nyanyian dibagikan kepada mahasiswa. Tugas mahasiswa adalah menyimak lagu/nyanyian tersebut lalu menulis ulang liriknya. Setelah itu, mahasiswa diperintahkan untuk mengidentifikasi ism, fi'il dan harf yang ditemukannya dari lirik lagu/nyanyian tersebut. Setelah batas akhir waktu pengumpulan tugas dan semua mahasiswa dipastikan telah mengumpulkan tugasnya maka dosen membagikan salinan lirik lagu/nyanyian tersebut lengkap dengan identifikasi ism, fi'il dan harfyang terkandung dalam lirik lagu/nyanyian tersebut. Melalui salinan yang telah dibagikan mahasiswa diminta mencocokkan salinan tersebut dengan hasil kerja mereka dengan kata lain evaluasi hasil kerja mahasiswa tidak semata-mata dilakukan oleh dosen melainkan mahasiswa juga dapat mengevaluasi sendiri kemampuan mereka dalam mengidentifikasi ism, fi'il dan harf dengan materi salinan yang telah dibagikan dosen sebagai acuan.Tujuannya agar mereka bisa paham letak kesalahan masing-masing.

2. Pekan kedua, masih dengan materi lagu/nyanyian yang sama. Pada pekan kedua, mahasiswa diperintahkan menyetor hafalan mufradāt yang terkandung dalam lirik lagu/nyanyian tersebut. Setelah itu mahasiswa diberi kebebasan memilih 10 mufradāt dari lirik lagu/nyanyian, yang dilanjutkan dengan membuat contoh kalimat singkat dan sederhana dari 10 mufradāt yang telah dipilihnya baik dalam bentuk jumlah ismiyyah maupun dalam bentuk jumlah fi'liyyah. Dalam artian kalimat yang dibuat tetap mengacu pada qawā'id yang telah mereka peroleh melalui materi pembelajaran bahasa Arab sebelumnya. Contoh kalimat itu dipersentsekan melalui pembelajaran video conference (dalam hal ini aplikasi yang digunakan adalah zoom) secara bergantian. Jadi mahasiswa dan dosen bersama-sama saling menyimak dan mengoreksi kalimat yang telah mereka buat.

3. Pekan ketiga, tentu saja masih dengan materi lagu yang sama, mahasiswa diwajibkan menghafalkan lagu tersebut dan menyetorkan rekaman video versi mereka masingmasing yang isinya adalah menyanyikan lagu tersebut. Dan pada akhir pertemuan pekan ketiga dosen kembali membagikan materi lagu/nyanyian yang berbeda. Demikian seterusnya.

Adapun lagu-lagu yang dibagikan ke mahasiswa yaitu lagu/nyanyian yang sedang trend di kalangan mahasiswa yang telah dicover berbahasa Arab oleh lembaga kursus bahasa Arab Al Azhar Pare Kediri. Sehingga dalam 8 pekan berturut-turut mahasiswa sudah menghafalkan 3 lagu. Strategi ini diterapkan dosen pengampu dengan inisiatif sendiri tidak 
lain bertujuan sebagai upaya menanggulangi stressor psikosial yang melanda mahasiswa sebagai dampak dari pembelajaran daring yang sarat dengan beban pemenuhan tugas dari hampir seluruh mata kuliah. Tentu saja dengan harapan melalui penerapan strategi ini dapat menarik kembali minat dan motivasi mahasiswa untuk mengikuti pembelajaran bahasa Arab daring sehingga tercapailah efektifitas pembelajaran bahasa Arab. Konkretnya strategi Karrona ini adalah strategi pembelajaran dengan menjadikan lagu/nyanyian sebagai media pemerolehan bahasa.

Strategi Karrona diyakini dosen efektif untuk diterapkan mengingat strategi tersebut cukup memenuhi unsur-unsur metode pembelajaran yang meliputi seleksi (materi), tahapan (tingkatan materi), presentasi (penyajian materi) dan repetisi (pengulangan). Selain itu juga strategi ini senadadengan prinsip-prinsip aliran linguistik struktural (Anshor, 2009) yang beranggapan bahwa (1) Bahasa merupakan hasil alat ucap. Oleh karena itu, keterampilan bahasa secara lisan merupakan hal yang harus dinomorsatukan. (2) Bahasa merupakan faktor kebiasaan (habit). Oleh karena itu, untuk menguasai keterampiulan berbahasa, seseorang harus melakukan latihan berulang-ulang. Emakin banyak berlatih, semakin baik penguasaan bahasa seseorang. (3) Mekanisme berbahasa merupakan suatu proses rangsang tanggapan (stimulus response). Oleh karena itu, di dalam latihan pelajar dibiasakan menanggapi secara spontan rangsangan yang diberikan.

Menyanyi merupakan kegiatan serius namun mengasyikkan, terlebih bagi siswa atau mahasiswa. Metode bernyanyi merupakan metode pembelajaran yang menggunakan syairsyair yang dilagukan. Dalam implementasinya, syair-syair tersebut harus disesuaikan dengan materi-materi yang akan diajarkan. Menurut para ahli, kegiatan bernyanyi membuat suasana belajar menjadi lebih menyenangkan sehingga pembelajaran dapat menjadi lebih efektif dan perkembangan siswa/mahasiswa dapat distimulasi secara lebih optimal (Ridwan \& Awaluddin, 2019). Hal ini dikarenakan bernyanyi merupakan aktifitas menggabungkan otak bagian kanan dan kiri secara bersamaan. Lirik lagu yang dinyanyikan merupakan hasil kinerja otak belahan kanan sedangkan nada adalah hasil dari kinerja olah bagian kanan (Suparman, 2010).

Strategi pembelajaran berbasis lagu/nyanyian ini diterapkan dengan maksud untuk menarik minat dan motivasi mahasiswa untuk kembali serius menjalani proses pembelajaran bahasa Arab daring. Besarnya tuntutan pemenuhan tugas dari hampir seluruh mata kuliah di tengah masa karantina tentu saja menjadi beban tersendiri bagi mahasiswa. Jenuh dengan 
kondisi serba terbatas selama masa karantina melahirkan kecemasan yang berdampak pada menurunnya minat dan motivasi mahasiswa untuk menjalani proses pembelajaran daring.

Bernyanyi memiliki berbagai manfaat. Di antaranya dapat meningkatkan oksigen karena pada saat bernyanyi seseorang mengambil nafas dan hal tersebut dapat meningkatkan oksigenasi dalam darah. Bernyanyi juga dapat meningkatkan ketahanan tubuh karena pada saat bernyanyi sistem imun juga meningkat sehingga tubuh tidak mudah terserang penyakit. Pada saat bernyanyi tubuh mengeluarkan kelenjar yang berfungsi sebagai pertahanan atau antibody. Bernyanyi dapat juga mengurangi stres atau rasa cemas karena dengan bernyanyi dan mendengarkan musik dapat menenangkan jiwa. Hal ini menyebabkan pikiran lebih rileks saat mendengarkan lagu dan ikut menyanyikannya (Citradewi et al., 2017).

Strategi pembelajaran berbasis lagu/nyanyian juga bermanfaat dalam melatih pelafalan kata/kalimat dengan baik. Dengan lirik lagu, mahasiswa dilatih untuk melafalkan kata/kalimat bahasa Arab dengan baik. Tugas menyetorkan hafalan mufradat pasca diperintahkan mengidentifikasi lafadz ism, fi'il dan harf yang terkandung lirik sebelum kegiatan pembuatan video adalah aktivitas yang diharapkan dapat melatih dan membiasakan mahasiswa berbahasa Arab dengan melafalkan kata/kalimat dengan baik meskipun hanya baru sebatas lagu.

Manfaat lain yang dapat diperoleh melalui strategi bernyanyi adalah dapat menambah daftar kosa kata (mufradat). Menyetorkan hafalan mufradat dan mengulangulangi lirik lagu dalam menghafalkan lagu/nyanyian sebelum membuat video cover lagu versi masing-masing mahasiwa secara otomatis menambahdaftar kosa kata/mufradat. Kualitas keteranpilan berbahasa seseorang bergantung pada kualitas dan kuantitas kosa kata yang dimiliki (Tarigan, 2008; Pauji, 2017). Semakin banyak kosa kata yang dimiliki seseorang maka akan semakin besar pula kemungkinan seseorang terampil dalam berbahasa.

\section{Respon Mahasiswa terhadap Penerapan Strategi Karrona dalam Pelaksanaan Pembelajaran Daring Bahasa Arab}

Melalui penerapan strategi Karrona yang berbasis media lagu diharapkan mampu menarik minat mahasiswa untuk aktif mengikuti kegiatan pembelajaran bahasa Arab daring minimal untuk penambahan dan penguasaan mufradāt dengan menyenangkan dan tanpa ada merasa beban. Terbukti penerapan strategi tersebut di tengah-tengah kejenuhan mahasiswa dalam menjalani pembelajaran daring ternyata mendapat respon yang sangat tinggi dari mahasiswa. Hal tersebut dapat dilihat dari hasil pada angket yang dibagikan yang 
menunjukkan bahwa sebanyak 85,8 \% responden yang merasakan besarnya pengaruh penerapan strategi Karrona terhadap minat belajar mereka pada mata kuliah bahasa Arab via daring selebihnya hanya sebesar $14,2 \%$ yang mengaku penerapan strategi tersebut tidak memberi pengaruh pada minat belajar bahasa Arab.

Menyikapi fenomena pembelajaran bahasa daring yang terkesan tidak efektif yang berdampak pada menurunnya minat dan motivasi mahasiswa sehingga berujung pada munculnya rasa jenuh. Maka dengan berbekal materi dasar yang telah diberikan sebelumnya, dosen berinisiatif untuk tidak lagi memberikan tambahan materi qawaid melainkan hanya memberikan tambahan mufradat melalui lagu-lagu yang dibagikan melalui grup Whatsapp yang wajib dihafalkan. Gambar 4 menunjukkan bahwa 95,5 \% atau sebanyak 168 orang dari 176 mahasiwa yang menanggapi bahwa strategi menghafalkan lagu-lagu tersebut sangat mempengaruhi pertambahan mufrädat/kosa kata bahasa Arab mereka. Hanya sekitar 8 orang $(4,5 \%)$ yang merasa strategi tersebut tidak berpengaruh pada penambahan mufrādat/kosa kata bahasa Arab mereka.
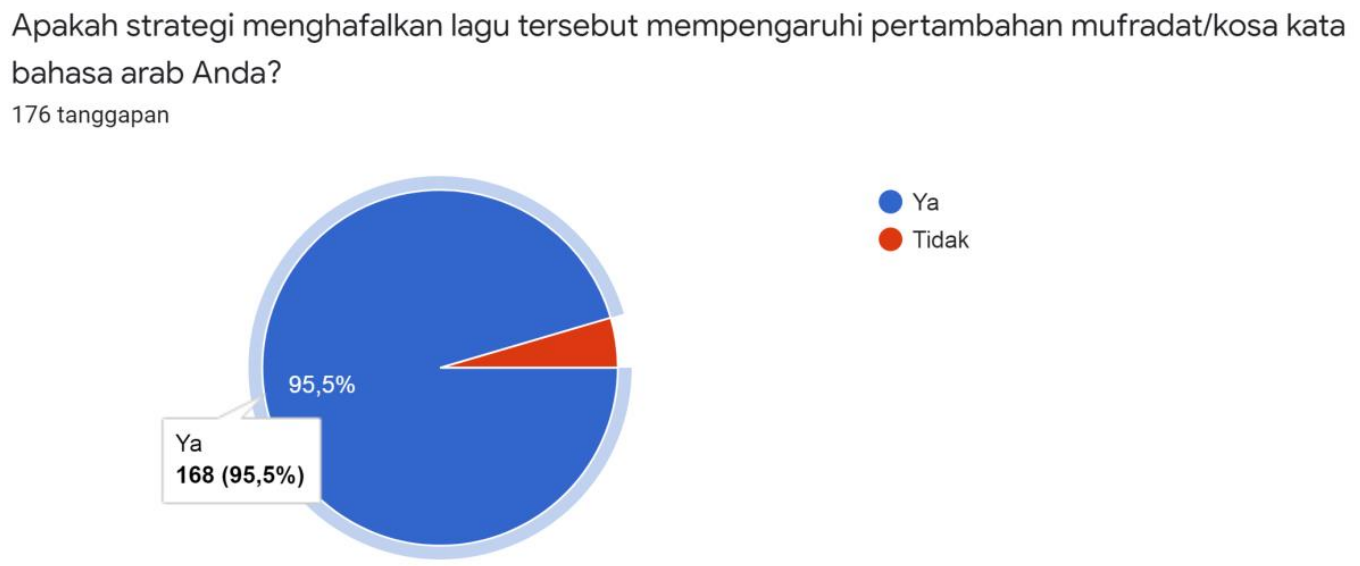

Gambar 4. Pengaruh Penerapan Strategi Karrona terhadap Pertambahan Mufradāt

Setelah tugas menghafalkan lagu, selanjutnya mahasiswa ditugaskan meng-cover ulang lagu tersebut versi mereka yang diabadikan dalam sebuah video. Hasil yang diperoleh menunjukkan sebanyak $86,4 \%$ responden mengaku bahwa strategi tersebut sangat menarik. Sedangkan 13,6 \% sisanya menanggapi jika tugas menghafalkan dan membuat video tersebut memberatkan. Data tersebut disajikan pada gambar gambar 5. 

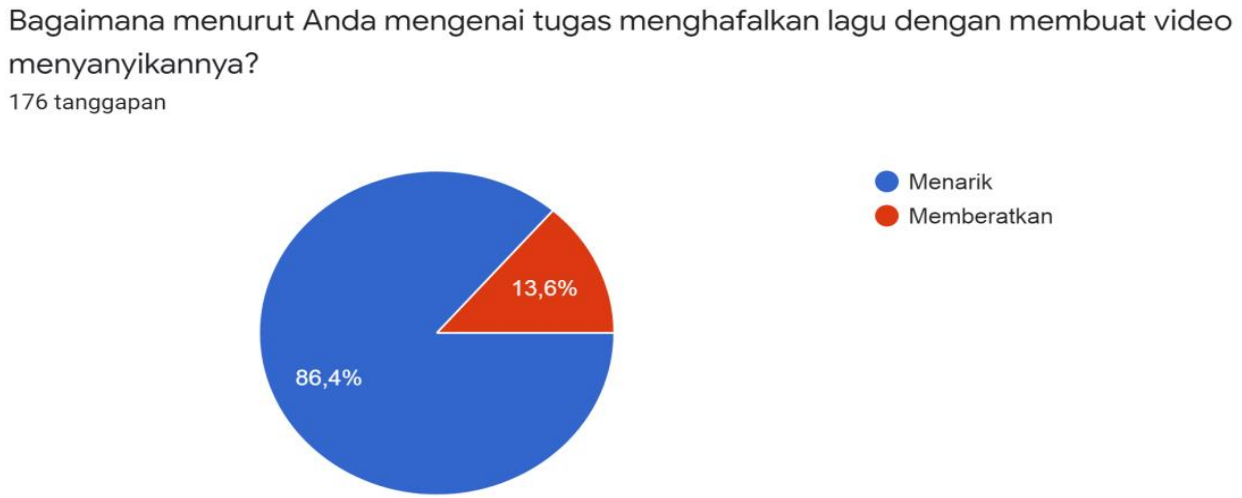

Gambar 5. Respon Mahasiswa terhadap Penerapan Strategi Karrona dengan Tugas Penghafalan Lagu dan Pembuatan Rekaman Video Bernyanyi

Pada dasarnya metode pembelajaran dengan berbasis media lagu/nysnyisn adalah pengembangan dari accelerated learning atau percepatan pembelajaran yang dianggap lebih efektif dan lebih cepat dibandingkan belajar secara konvensional, dikembangkan pada pertengahan 1970 berdasarkan kerja Dr. George Lazanov (Qomaruddin, 2017). Model ini menitikberatkan pada pemberdayaan siswa untuk belajar lebih cepat, efektif danlebih menyenangkan, sehingga materi akan lebih bermakna dan daya ingatnya lebih kuat. Materi yang disuguhkan yaitu dengan menggabungkan musik atau lagu.

\section{SIMPULAN DAN SARAN}

Dalam menjalani proses pembelajaran bahasa Arab daring selama masa pandemi, banyak hal yang menjadi kendala yang dirasakan oleh dosen pengajar tidak terkecuali para mahasiswa. Keterbatasan penguasaan aplikasi penunjang pembelajaran daring oleh dosen maupun mahasiswa berimplikasi pada banyaknya mahasiswa yang mengeluhkan ketidakefektifan proses pembelajaran daring. Kurang efektifnya pembelajaran daring akhirnya mempengaruhi minat dan motivasi mahasiswa, serta menimbulkan stressor psikosial di kalangan mahasisw. Strategi Karrona yang merupakan strategi pembelajaran berbasis media lagu/nyanyian adalah strategi yang diterapkan dosen pengampu Bahasa Arab dalam menyikapi realitas ketidak efektifan pembelajaran. Hal ini disambut dengan antusias oleh mahasiawa. Terbukti strategi tersebut dapat mengatasi kejenuhan mahasiswa menjalani proses pembelajaran daring dan berhasil menarik kembali minat dan motivasi mahasiswa dalam menjalanipembelajaran daring. Strategi Karrona bisa menjadi salah satu metode pengajaran yang dapat diimplementasikan dalam hal peningkatan pemahaman qawāid sekaligus peningkatan penguasaan mufradāt. Penerapan strategi Karrona tersebut 
diharapkan mampu menarik minat anak untuk melakukan kegiatan pembelajaran penguasaan kosakata bahasa Arab dengan menyenangkan dan tanpa ada merasa beban agar proses pembelajaran dapat berjalan dengan baik dan tujuan pembelajaran dapat tercapai. Dengan materi lagu/nyanyian mahasiwa tidak merasa jenuh, bosan dan sulit untuk menguasai kosakata. Ketika sudah tertarik untuk melakukan pembelajaran dengan menggunakan metode bernyanyi maka akan mudah dalam mengikuti setiap tahapan pembelajaran dan akan mudah untuk menguasai dan menghafal mufradāt.

Penelitian ini diupayakan berlanjut agar tidak terhenti pada fase tersebut. Diharapkan peneliti selanjutnya bisa mengeksplorasi dengan mencoba melakukan studi komparasi apakah implementasi strategi Karrona terhadap mahasiswa dengan latar belakang pendidikan dari MA/Pesantren dapat menghasilkan output berupa tingkat penguasaan bahasa Arab dan kemahiran berbahasa Arab yang berkembang jauh lebih pesat dibanding mahasiswa dengan basic umum (SMU/SMK) yang minim pengetahuan dasar ataukah tidak ada perbedaan sama sekali. Tentunya pelaksanaan penelitian selanjutnya diharapkan dengan mengimplementsikan strategi Karrona ini secara terencana agar dapat dikaji lebih dalam dan diidentifikasi letak kelebihan dan kekurangan dari strategi ini.

\section{DAFTAR PUSTAKA}

Anshor, A. M. (2009). Pengajaran Bahasa Arab: Media dan Metode-Metodenya. Teras.

Anugrahana, A. (2020). Hambatan, solusi dan harapan: pembelajaran daring selama masa pandemi covid-19 oleh guru SD. Scholaria: Jurnal Pendidikan Dan Kebudayaan, 10(3), 282-289. https://doi.org/10.24246/j.js.2020.v10.i3.p282-289

Argaheni, N. B. (2020). Sistematik review: dampak perkuliahan daring saat pandemi covid19 terhadap mahasiswa Indonesia. PLACENTUM Jurnal Ilmiah Kesehatan Dan Aplikasinya, 8(2), 99-108.

Citradewi, D. A., Suerni, T., \& Widiyanto, B. (2017). Efektivitas terapi bernyanyi (mantra om) terhadap tingkat ansietas siswa menjelang ujian di SMAN 1 Kradenan. Jurnal Ilmu Keperawatan Dan Kebidanan, 6(1), 1-10.

Creswell, C. (2009). Research design: Qualitative, quantitative, and mixd methods approaches. Thousand Oaks. SAGE Publications.

Creswell, J. W. (2012). Educational research: Planning, Conducting and Valuating Quantitative and Qualitative Research (4th ed.). Pearson.

Gunawan, G., Suranti, N. M. Y., \& Fathoroni, F. (2020). Variations of Models and Learning Platforms for Prospective Teachers During the COVID-19 Pandemic Period. Indonesian Journal of Teacher Education, 1(2), 61-70. 
Hanson, W. E., Creswell, J. W., Clark, V. L. P., Petska, K. S., \& Creswell, J. D. (2005). Mixed Methods Research Designs in Counseling Psychology Mixed Methods Research Designs in Counseling Psychology. Journal of Counseling Psychology, 52(2), 224-235. https://doi.org/10.1037/0022-0167.52.2.224

Hidayat, N. S. (2012). Problematika Pembelajaran Bahasa Arab. Jurnal Pemikiran Islam, $37(1), 82-89$.

Hutauruk, A., \& Sidabutar, R. (2020). Kendala pembelajaran daring selama masa pandemi di kalangan mahasiswa pendidikan matematika: kajian kualiatatif deskriptif. SEPREN: Journal of Mathematics Education and Applied, 2(1), 45-51.

Kusuma, J. W., \& Hamidah. (2020). Perbandingan hasil belajar dengan penggunaan platform WA Group dan webinar zoom dalam pembelajaran online. Jurnal Ilmiah Pendidikan Matematika, 5(1), 97-106.

Mustofa, B., \& Hamid, A. (2016). Metode dan Strategi Pembelajaran Bahasa Arab (I. Muslimin (ed.); IV). UIN-Maliki Press.

Pauji, M. (2017). Pengaruh Penguasaan Kosakata terhadap Kemampuan Berpidato. Jurnal Diksatrasia, 1(2), 268-272.

Qomaruddin, A. (2017). Penerapan Metode Bernyanyi dalam Pembelajaran Mufradat. Jurnal Tawadhu, 1(2), 272-290.

Rahmasari, A. F., Setiawan, F., \& Faradita, M. . (2020). Pengaruh pembelajaran online terhadap kemandirian belajar siswa kelas II SD Muhammadiyah 17 Surabaya di tengah pandemi covid-19. Inventa: Jurnal Pendidikan Guru Sekolah Dasar, 4(2), 158-168. https://doi.org/10.36456/inventa.4.2.a2609

Ridwan, \& Awaluddin, A. F. (2019). Penerapan Metode Bernyanyi dalam Meningkatkan Penguasaan Mufradat dalam Pembelajaran Bahasa Arab di Raodhatul Athifal. DIDAKTIKA : Jurnal Kependidikan, 13(1), 56-67.

Rigianti, H. A. (2020). Kendala pembelajaran daring guru SD di Kabupaten Banjarnegara. Elematary School, 7(2), 297-302.

Sadikin, A., \& Hamidah, A. (2020). Pembelajaran daring di tengah wabah covid-19. BIODIK: Jurnal Ilmiah Pendidikan Biologi, 6(2), 214-224.

Sanjaya, W. (2006). Strategi Pembelajaran Berorientasi Standar Proses Pendidikan. Kencana Prenada Media Group.

Suhendro, E. (2020). Strategi pembelajaran pendidikan anak usia dini di masa pandemi covid-19. Golden Age: Jurnal Ilmiah Tumbuh Kembang Anak Usia Dini (JGA), 5(3), 133-140.

Sumardi, M. (1996). Berbagai Pendekatan dalam Pengajaran Bahasa dan Sastra. Pustaka Sinar Harapan.

Suparman, S. (2010). Gaya Mengajar yang Menyenangkan Siswa. Pinus Book Publisher. 
Tarigan, H. G. (2008). Menulis sebagai Suatu Keterampilan Berbahasa. Angkasa.

Turdjai. (2016). Pengaruh Pendekatan Pembelajaran terhadap Hasil Belajar Mahasiswa. Triadik, 15(2), 17-29.

Wargadinata, W., Maimunah, I., Ramadhanti, F., \& Humaira, L. (2020). Mediated arabic language learning for arabic students of higher education in covid-19 situation. Izdihar: Journal of Arabic Language Teaching, Linguistics and Literature, 3(1), 59-78.

Watnaya, A. kusnayat, Muiz, M. hifzul, Sumarni, N., Mansyur, A. salim, \& Zaqiah, Q. yulianti. (2020). Pengaruh teknologi pembelajaran online di era covid-19 dan dampaknya terhadap mental mahasiswa. EduTeach: Jurnal Edukasi Dan Teknologi Pembelajaran, 1(2), 153-165. https://doi.org/10.37859/eduteach.v1i2.1987

Yulita, H. (2014). Faktor-Faktor yang Mempengaruhi Efektifitas dan Motivasi Belajar Mahasiswa dalam Menggunakan Metode Pembelajaran E-Learning. Business \& Management Journal Bunda Mulia, 10(1), 106-119.

Zullaini, N. N., Mufadah, N., Kholis, N., \& Amrulloh, M. . (2020). Learning arabic for elementary schools during the covid-19 outbreak. AL-MUDARRIS: Journal of Education, 3(1), 39-55. 